International

Medical Society

http://imedicalsociety.org

\title{
Work Ability of Nurses in Primary Health Care
}

Maria Aparecida da Silva1, Soraya Maria de Medeiros², Ana Elisa Pereira Chaves ${ }^{3}$, Joselito Santos ${ }^{4}$, Yanna Gomes de Sousa ${ }^{5}$, Daniele Rezende ${ }^{5}$

\section{Abstract}

Objective: To evaluate the Work ability index for nurses in primary health care considering the sociodemographic factors and health conditions of workers.

Methods: A Cross-sectional study, of a quantitative approach involving 70 nurses of the Family Health Strategies of a municipality in northeastern Brazil. Data collection occurred during the months of May and June 2015 and used the Brazilian version of a standardized questionnaire to calculate Work Ability Index. For data analysis, the Statistical Package for the Social Sciences (SPSS) was used for descriptive analysis, from the distribution of absolute and relative frequencies of the sociodemographic and labor variables.

Results: As a result, it is highlighted that $51.5 \%$ of nurses reported "good" current work ability. However, the disease diagnosed more frequently in the last 12 months were musculoskeletal diseases, remaining the endocrine, gastrointestinal and respiratory diseases at the same level.

Conclusion: It is concluded that the high percentage of workers with a good ability to work. However, there is a need to restore the physical and physiological state of nurses working in primary health care. The mentioned strategies aim to maintain a safe and adequate working environment and encourage healthy lifestyle habits and provide permanent training.
1 Nurse. Master in Program in Public Health and Hospital Management. The Northern School of Paraná - Facnorte. Campina Grande(PB), Brazil.

2 Nurse. Ph.D. in Health Science. Professor of the Graduate Program in Nursing/ School of Nursing Technician, Federal University of Rio Grande does Norte/UFRN. Natal(RN), Brazil.

3 Nurse. Master in Nursing. Professor of the Nursing Department, Federal University of Campina Grande/UFCG. Campina Grande(PB), Brazil.

4 Ph.D. Professor of Northern Paraná School - Facnorte- Department of Graduate Studies and Research Master's Program in Public Health and Hospital Management. Campina Grande(PB), Brazil.

5 Nurse. Master student of the Graduate Program in Nursing, Federal University of Rio Grande do Norte/UFRN. Natal(RN), Brazil.

\section{Contact information:}

Yanna Gomes de Sousa.

¡yanna_gomes@yahoo.com.br

\section{Keywords}

Occupational Health; Nursing Work; Health Strategy; Work Ability

Assessment. 


\section{Introduction}

In recent decades, several initiatives of the Brazilian society have been seeking to consolidate advances in the public policy of comprehensive care in Occupational Health $(\mathrm{OH})$. The initiatives include actions involving assistance, promotion, monitoring and prevention of diseases related to work [1].

However, public health in Brazil and the world related to workers' health have a major problem that arises from the worker's health profile modification with a high increase in diagnoses of musculoskeletal disorders, change in the psychological capacity and aging workforce that consequently influences the ability to work [2].

Studies [3] investigating the ability to work began in Brazil after the translation and adaptation of the Brazilian version questionnaire by Fischer. The health sector has been highlighted in conducting research to evaluate the ability to work, and their results and reflections have contributed to strengthening the Occupational Health Policy.

From the perspective of workers' health, the ability to work is about the potential of workers to perform their tasks by the requirements of the job, their health and their physical and mental abilities. These aspects need to be maintained at all stages of their working life [4]

Concerning the nursing area, the research to evaluate the ability to work is greater in tertiary care units. In 2009, a reseach [5] of 68 nurses in the emergency room of Rio Grande do Sul found that $42.9 \%$ nurses had low or moderate work ability index. Repeated respiratory tract infections, back injury, varicose veins, mild emotional disturbance, vision problems and disease of upper back or neck, with frequent pain were the diseases more frequently diagnosed.

In the primary health care context, besides the issues that permeate the specifics of the nursing actions on the FHS (Family Health Strategy, there are other problems related to fragile employment contracts, requirements for a construction of a mo- difier acting, and pressures to achieve the goals of health programs [6].

Health can contribute to nursing knowledge in the area of occupational health and can facilitate the transformation of the practices of managers and workers to promote health while studying the identification of harmful effects of nurses' work. Also, the identification to reduce ability to work is an important indicator that helps managers and workers in the adoption of promotional measures to prevent health problems and absenteeism/disease.

Due to this statement, and aware that much attention has been given to workers in the hospital sector and little attention to FHS workers, there was the interest in the topic if the Family Health Strategy-FHS. The study is relevant since there are scarce approaches involving this proposal. However, it is expected that this research will help the formulation of health promotion strategies at work for FHS nursing staff. Nevertheless, it is expected that the article is a research resource for further investigation.

On worker health context and consideration of the ability to work, this study aims to assess the Work Ability Index (WAI) of nurses in the Family Health Strategy-FHS.

\section{Methods}

The study was developed in the Family Health Strategies - FHS in Campina Grande, PB, related to the Health Municipal Secretary. Currently, the municipality has 94 FHS teams and 76 FHU (Family Health Units), where $71 \mathrm{FHU}$ are in the urban areas and 05 in the rural area. The coverage of the number of Family Health Teams related to the population is $86 \%$.

This is a cross-sectional research, of a quantitative approach, using the data collection method (survey) [7] with questionnaires applied in person. The target population was nurses from the Family Health Program in Campina Grande, Paraíba. 
As the inclusion criteria for the sampling process were nurses of the FHS working team of the city, agreeing to participate in the study voluntarily and signing the Informed Consent Form (ICF) and present at the FHU at the time of research. Nurses who have been removed from service for leave, health or vacation were excluded.

The study population consisted of 94 nurses, of which 70 remained after the application of the inclusion and exclusion criteria. A confidence level of 95\% with a maximum error in the proportion of $5 \%$ was used to estimate the sample size. The application of these parameters for the sample size calculation, performed with the WinPepi software, version 1.31, 2004, produced sample size of 70 nurses.

The Research Ethics Committee (CEP) of Campina Grande Health Department CAAE No 42284815.8.0000.5186 approved the research project.

Data collection was conducted through a selfapplied questionnaire, assessing the sociodemographic and labor characteristics such as the Work Ability Index (WAI), which describes the worker's selfassessment of the capacity to work [9] and physical activity practice habits. The period of data collection was from May to June 2015, totaling 30 days.

In the mid-80s, an instrument to evaluate the Work Ability Index (WAI) was developed in Finland [8] translated and adapted to Portuguese by researchers of the University of São Paulo, in collaboration with other Brazilian universities and institutions.

It is a self-applicable questionnaire composed of ten items, synthesized in seven dimensions: (1) ability to work compared to the best ability of their lives, (2) ability to work in their physical requirements, (3) number of current diseases diagnosed by the doctor (4) loss estimated for work because of illness, (5) absence from work for illness in the last 12 months, (6) self-prognosis of the ability to work in 2 years and (7) mental resources [3].

In the data analysis, the Statistical Package for the Social Sciences (SPSS) was used for descriptive analysis from the distribution of absolute and relative frequencies of sociodemographic variables, labor and physical activity practice habits. Then, tables, chart and bars and radial graphics were built to elucidate the data obtained in a practical way.

\section{Results}

The study population consisted of 70 nurses who presented sociodemographic characteristics shown in Table 1.

Table 1. Sociodemographic profile of the nursing staff of primary health care, Campina Grande, Paraíba, Northeastern Brazil, in 2015.

\begin{tabular}{|c|c|c|}
\hline $\begin{array}{c}\text { Sociodemographic } \\
\text { characteristics }\end{array}$ & $\begin{array}{c}n \\
(\%)\end{array}$ & $\begin{array}{l}\text { Total } \mathbf{n} \\
(\%)\end{array}$ \\
\hline \multicolumn{3}{|l|}{ Gender } \\
\hline Male & $66(94.3)$ & \multirow{2}{*}{10 (100) } \\
\hline Female & $04(5.7)$ & \\
\hline \multicolumn{3}{|l|}{ Age (in years) } \\
\hline From 30 a 39 years old & $30(43)$ & \multirow{4}{*}{70 (100) } \\
\hline From 40 a 49 years old & $22(31)$ & \\
\hline From 50 a 59 years old & $15(21)$ & \\
\hline No answer & $2(3)$ & \\
\hline \multicolumn{3}{|l|}{ Marital Status } \\
\hline Single & $15(21)$ & \\
\hline Live with a partner & $08(11.5)$ & \\
\hline Divorced & $08(11.5)$ & \\
\hline Widow & $00(00)$ & \\
\hline \multicolumn{3}{|l|}{ Acting Geographic Area } \\
\hline Urban & 59 (84.5) & \multirow{3}{*}{$70(100)$} \\
\hline Rural & $06(8.5)$ & \\
\hline Urban/Rural & $05(7)$ & \\
\hline \multicolumn{3}{|l|}{ Time of working in the ESF } \\
\hline Less than 10 years & $14(2)$ & \\
\hline From 10 to 19 years & $49(7)$ & 2.0 \\
\hline \multirow[t]{2}{*}{ From 20 or more } & $7(1)$ & 7.0 \\
\hline & 7 & 1.0 \\
\hline
\end{tabular}

Source: SILVA, MA. Direct data collection through a questionnaire. *Multiple choice question 
Table 2 Distribution of Primary health Care nursing staff, according to the Work Ability Index (WAI) (N=70). Campina Grande, Paraíba, Northeastern Brazil, in 2015.

\begin{tabular}{|c|c|c|}
\hline $\begin{array}{l}\text { Distribution of Primary health } \\
\text { Care nursing staff }\end{array}$ & $\begin{array}{c}n \\
(\%)\end{array}$ & $\begin{array}{l}\text { Total } n \\
(\%)\end{array}$ \\
\hline \multicolumn{3}{|c|}{ Classification of the Current Work Ability } \\
\hline Very good & $11(16)$ & \multirow{5}{*}{$70(100)$} \\
\hline Good & $36(51.5)$ & \\
\hline Moderate & $20(28.5)$ & \\
\hline Low & $03(4)$ & \\
\hline Very Low & $0(0)$ & \\
\hline \multicolumn{3}{|c|}{ Work Ability according to the demands } \\
\hline Very good & $17(24)$ & \multirow{5}{*}{$70(100)$} \\
\hline Good & $31(44)$ & \\
\hline Moderate & $21(30)$ & \\
\hline Low & $01(2)$ & \\
\hline Very low & $0(0)$ & \\
\hline
\end{tabular}

The distribution of nurses according to the WAI is shown in Table 2. Out of the respondents, 51.5\% obtained WAI classification as "good", 28.5\% as "moderate" and 4.0\% as "low" ability to work.

Concerning the ability to work according to the demands, there were 44\% having a good capa-

Figure 1: Number of workers affected by the type of diseases with a medical diagnosis for effective FHS nurses in Campina Grande, Paraiba, Brazil, in 2015.

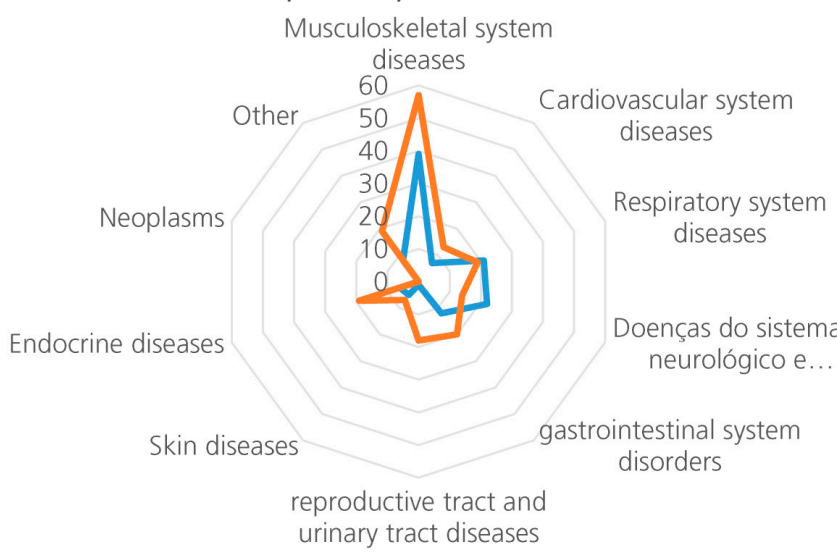

Worker's opinion $\longrightarrow$ Medical diagnosis

Source: SILVA, MA. Direct data collection through a questionnaire. *Multiple choice question
Table 3 Distribution of the impact of diseases on the labor development of FHS nurses in Campina Grande, Paraiba, Brazil, in 2015.

\begin{tabular}{|c|c|}
\hline Impact of diseases on the labor & n (\%) \\
\hline \multicolumn{2}{|l|}{ Estimated work losses due to disease } \\
\hline Not having any disease or disability & $22(31.5)$ \\
\hline Developing work, but causing symptoms & $38(54)$ \\
\hline $\begin{array}{l}\text { Sometimes changing or decreasing pace or } \\
\text { working method }\end{array}$ & $07(10)$ \\
\hline Often changing rhythm or working method & $0(0)$ \\
\hline $\begin{array}{l}\text { Feeling the need to work part-time because of } \\
\text { the disease }\end{array}$ & $0(0)$ \\
\hline Totally unable to work & $01(1.5)$ \\
\hline No answer & $02(3)$ \\
\hline Total & $70(100)$ \\
\hline \multicolumn{2}{|l|}{ Absence from work on days due to diseases } \\
\hline None & $25(36)$ \\
\hline Up to 9 days & $39(54)$ \\
\hline From 10 to 24 days & $03(4)$ \\
\hline From 25 to 99 days & $03(4)$ \\
\hline From 100 to 365 days & $0(0)$ \\
\hline Total & $70(100)$ \\
\hline
\end{tabular}

Self-prognosis on the ability to develop the current job in the next two years

Unlikely

I am not too sure

It is quite likely

Total

$70(100)$

Source: SILVA, MA. Direct data collection through a questionnaire. *Multiple choice question

city, 30\% moderate and $24 \%$ very good capacity to work.

As for work lost due to diseases, it was observed that $54 \%$ of nurses reported symptoms during the development of labor activity. It was also found that $54 \%$ nurses missed working for up to nine days due to some disease. Regarding the self-prognosis on the ability to develop the current job for the next two years, $95 \%$ of nurses say it was possible to happen. [5] (Table 3) 
The main groups of diseases that affect nurses in their perspective and with diagnosis confirmed by a doctor are musculoskeletal diseases, remaining the endocrine, gastrointestinal and respiratory diseases at the same level, disease of the reproductive and urinary system as the third level, followed by neurological and emotional disorders, and discretely skin diseases and tumors. An important fact pointed out in this study was the presence of more than one diagnosis in nurses. (Figure 1)

\section{Discussion}

The sociodemographic characteristic shows that the study population is predominantly female (94.3\%). The age range observed was from 30 to 39 years old $(43 \%)$.

The results of this study indicate that sociodemographic characterization of the nurses in the study is similar to samples of nurses from other investigations. [9-10] According to gender and marital status, results are consistent with national studies showing that nursing remains an essentially female profession. Since the nineteenth century, most of the nurses are married women who combine their professional duties of the care and the home, the children, and the spouse. These women work features make a conflict in their integration in the labor market. [11]

Concerning to age, it is realized that most of the nurses in this study are over 30 years old. Studies have shown that aging causes changes in the body and progressive loss of ability to work. Being 30 years old, the individual reaches the maximum of intellectual, sensory and motor development, and may achieve excellence in their performance, but adversity can anticipate the physiological aging and affect the ability to work [12].

Another study [13] concludes that from 45 years old, the physiological functions begin to deteriorate, affecting cardiorespiratory and musculoskeletal capacity. There is also decreased perception; infor- mation processing becomes slow and a decline in memory function, all related to aging that affects mental capacity.

Regarding marital status, 56\% were married, 21\% were single, $11.5 \%$ were in union with a partner, $11.5 \%$ were divorced, and there were not widows. Thus, $67.5 \%$ of nurses live in a relationship with a partner. Regarding marital status, some research shows that the fact of having a partner and children suggests that the individual, after their work activities, is replaced by extra demand with the family, although they have a housekeeper [12].

In the professional practice, $70 \%$ of nurses are working in the FHS of the municipality between 10 and 19 years as effective professionals, 20\% work less than ten years, and $10 \%$ of nurses work 20 years or more. Thus, $84.5 \%$ of professionals work in Health Units in the urban area; only $8.5 \%$ in rural areas and $7 \%$ work in the two geographical areas.

Regarding the working time, a study showed [14] that the time participation of nurses in the labor market was about $50 \%$ in the first ten years of professional practice and $25 \%$ between 11 to 20 years. It is noteworthy that in the first year of professional practice, there is $10 \%$ of nurses' avoidance of labor market. Given these results, there is a gradual increasing emptying of approximately $89 \%$ of the workforce, which represents a loss of potential years of study, the social cost of graduation and even personal investments.

The results showed that $51.5 \%$ of the population surveyed have a good ability to work, $28.5 \%$ have a moderate ability, and $4.0 \%$ have a "low" capacity for work. In the individual assessment, the nurses surveyed had a higher percentage score for good, fact similar to other studies that evaluated the ICT in nursing professionals [5, 12, 13, 15]

It is noteworthy that the work of nurses in the FHSs requires skills to develop assistance activities at the health facility and community, and planning and evaluation of the team in action, as well as supervision of the Community Health Agent. The 
performance of these activities requires intellectual, physical and psychological conditions.

An international study on work ability index in nurses showed that $32.0 \%$ of workers reported moderate capacity for work. [16]

Another study [17] found that in the work situation, the continuous requirements requested in the workplace could cause damage to physical and/or mental workers. Such working conditions can occur together with problems related to forms of work organization and leaders profile of public and private institutions.

In relation to days lost from work due to illness, $54 \%$ of workers showed that they missed up to 9 working days for this reason; $36 \%$ of professionals have not missed any workday, only $10 \%$ required from 10 to 24 days on leave, and the same percentage asked for 100 to 365 days.

In this study, a higher percentage of FHS nurses can carry out their work even feeling any symptoms. Nursing workers perform their activities, even worn and exhausted of the labor force due to the control that the job requires. Acting in this way, the worker can present some suffering and discouragement, anxiety, conflict in the team, absorption user problems for them, professional devaluation, work overload and impotence facing the difficulty of accounting for the demand [18].

When asked about the self-prognosis on their ability to develop the current job in the next two years, $91.5 \%$ of the professionals highlighted is quite likely that they can perform the required labor actions.

Predicting the performance of the current job for two years from now is sometimes predicting the uncertain since the work carried out in basic care need the ability to teamwork, emotional balance, and self-control in stressful situations, which may compromise the physical and mental health of the worker and their ability to work. However, this is an important fact, assessed in WAI because the signals perception of workers about their situation in a future perspective [3].
When a professional concern or a possible positive outcome of his work performance capacity in the future, current ability to develop his work is declared, even in the face of threats, illness, and absenteeism [19].

In this study, musculoskeletal diseases stood out as those that most affect nurses with medical diagnosis. There were 57 nurses reported being affected by an injury to the upper limbs, lower back, and neck and/or developed any disease related to the joints. At the same level, it appears endocrine, gastrointestinal and respiratory diseases followed by diseases of the reproductive tract and urinary tract, and lastly the neurological, emotional skin diseases and tumors.

The higher prevalence of musculoskeletal diseases, both self-reported as the physician-diagnosed are also presented in the studies of other authors who have researched the ability to work. These diseases have been identified as major contributors to reduced functional capacity due to the physical and mental burden on nursing staff [20].

There are also highlighted cardiovascular diseases from high blood pressure and stroke, acute myocardial infarction or chronic diseases related to the system, 13 nurses reported a confirmed diagnosis. Respiratory diseases such as asthma, emphysema, bronchitis, and sinusitis affected 19 workers; neurological and emotional disorders, mainly mild emotional disturbance reached 14 nurses with established diagnosis.

Gastrointestinal diseases that include gastritis, colitis, and the pancreatic disease reached 20 participants from researched nurses. Kidney disease and genitals reached 18 nurses based on medical diagnosis. Endocrine diseases affected 19 workers confirmed the diagnosis of diabetes, seven nurses reported some skin disease; no malignancy was mentioned.

The highest number of sickness absenteeism observed among nursing workers is a greater incidence caused by musculoskeletal disease and depression. [21-22] 
Emotional disorders such as depression, anxiety and insomnia occur more frequently in nursing due to conflicting work environment. This situation can be explained by the tension generated by stress, found in work overload, poor working conditions, the team relationship and the many problems that affect patients and the community [23].

Even considering the limits of their current state of health and the adversities that nurses face acting in the FHS, it was observed certain satisfaction from their work in the FHS. This can translate into commitment, responsibility, and greater affirmation of their professional identity [24].

Job satisfaction contributes to the increased participation of workers in their working environment, as people met at work adopt positive attitudes with them and the team. In this sense, the job satisfaction becomes a tool in the pursuit of quality, being a dynamic process that influences the work organization and the workers' social life [25].

It is understood that this study brings contributions to nursing, since as highlighting limitations to work in individuals surveyed due to comorbidities and inevitably to indicate that there may be consequences and implications for the health of nurses and this requires managers' effective and focused actions on the health of these workers.

It is worth remembering that the reality of the working world is more complex than the results achieved by a study. However, it is considered that within the limitations inherent to the cross-sectional study, these results help to reinforce some findings of other studies, consolidating the adopted reference [WAI)

\section{Final Considerations}

This study identified that $51.1 \%$ of the nursing workers have a good capacity for work. However, the disease diagnosed more frequently in the last 12 months were musculoskeletal diseases, remaining the endocrine, gastrointestinal and respiratory diseases at the same level. Such findings indicate the importance of management in primary support measures directed to these individuals because they can become incapacitated for work activities over time.

It is recommended that some actions in promoting health quality of nurses are implemented such as maintain a safe working environment and appropriate work to ergonomic issues; encourage healthy lifestyle habits and provide permanent training.

This reality of the work environment needs to be known by managers. They must individually know the work and health condition of nurses and all family health team to engage them in collective discussions to seek the development of programs related to worker health.

\section{References}

1. Lacaz FAC. Política Nacional de Saúde do Trabalhador: desafios e dificuldades. In: Lourenço E. et al. (Org.). O avesso do trabalho II: trabalho, precarização e saúde do trabalhador. São Paulo: Expressão Popular; 2010. p. 199-230.

2. Isosaki M, Cardoso E, Glina DMR, Alves ACC, Rocha L. Prevalência de sintomas osteomusculares entre trabalhadores de um Serviço de Nutrição Hospitalar em São Paulo, SP. Rev. bras. saúde ocup. 2011; 36(124): 238-246.

3. Fischer FM. Breve histórico desta tradução. In: Tuomi K, Ilmarinen J, Jahkola A, Katajarinne L, Tulkki A. Índice de capacidade para o trabalho. São Carlos: EduFSCar; 2005. p. 9-10.

4. Martinez MC, Latorre MRDO, Fischer FM. Capacidade para o trabalho: revisão de literatura. Ciênc. saúde coletiva. 2010; 15(Suppl 1): 1553-1561.

5. Tânia SBSM de, Carmem LCB, Patrícia BTG, Juliana PT, Andrea $\mathrm{P}$, Rosângela MS da. Avaliação da capacidade para o trabalho dos trabalhadores de enfermagem de pronto-socorro. Revista Eletrônica de Enfermagem. 2013; Goiana, v. 15, n. 2, p. 523532, abr./jun. Doi: http://dx.doi.org/10.5216/ree.v15i2.15344

6. Vanezia GS, Maria CSM, Regina CGZ. A prática do enfermeiro na Estratégia Saúde da Família: o caso do município de Vitória/ ES. Revista Eletrônica de Enfermagem. 2010; v. 12, n. 3, p. 441448, 2010. Doi: http://dx.doi.org/10.5216/ree.v12i3.5278.

7. Callegari-Jacques SM. Bioestatística: princípios e aplicações. Porto Alegre: Artmed; 2003

8. Tuomi K. et al. Summary of the finnish research project (19811992) to promote the realth and work ability of aging workers. Scand J Work environ health, n. 23, v. 1, 1997. 
9. Sancinetti TR. et al. Absenteísmo - doença na equipe de enfermagem: relação com a taxa de ocupação. Rev. esc. enferm. USP. 2009; vol.43, n.spe.2, pp. 1277-1283.

10. Silva FJ. A Capacidade para o trabalho e fadiga entre trabalhadores de enfermagem [dissertação]. São Paulo: Escola de Enfermagem da Universidade de São Paulo/USP; 2011. 85p.

11. Dalri RCMB. Carga horária de trabalho dos enfermeiros de emergência e sua relação com o estresse e cortisol salivar [tese]. São Paulo: Universidade de São Paulo. Ribeirão Preto/USP; 2013. $205 p$.

12. Hilleshein EF, Lautert L. Capacidade para O trabalho, características sociodemográficas e laborais de enfermeiros de um hospital universitário. Rev. Latino-Am. Enfermagem. 2012; vol.20, n.3, pp. 520-527.

13. IAP Walsha. et al. Capacidade para o trabalho em indivíduos com lesões músculo esqueléticas crônicas. Revista de Saúde Pública. 2004; n. 38, v. 2, p.149-156. Doi: http://dx.doi.org/10.1590/ S0034-89102004000200001

14. Lenice CMS de, Elizabeth PG, Maria EAF, Mariana SGS, Karine AMN. Tempo de atuação do profissional enfermeiro - Minas Gerais. Enfermagem em Foco. 2011; v.2, n. 4 p.248-250.

15. Dias RMB. Índice de capacidade para o trabalho e satisfação com a profissão: um estudo relacional com docentes de uma instituição pública de ensino superior. [dissertação] Natal -RN: Programa de Pós-Graduação Strictu-Sensu em Administração/ UNP; 2014. 102p.

16. Bethge M, Radoschewski FM, Müller-Fahrnow W. Work stress and work ability: cross-sectional findings from the German Sociomedical Panel of Employees (SPE) Disabil Rehabil. 2009; 31(20):1692-1699. Doi: 10.1080/09638280902751949.

17. Silva EF da, Oliveira KKM de, Zambroni-de-Souza PC. Saúde mental do trabalhador: o assédio moral praticado contra trabalhadores com LER/DORT. Rev. bras. saúde ocup. 2011; v.36(123), p. 56-70. Doi: http://dx.doi.org/10.1590/5030376572011000100006 .

18. Ribeiro SFR, Martins STF. Sofrimento psíquico do trabalhador da saúde da família na organização do trabalho. Psicologia em Estudo. 2011; v. 16, n.2, p.241-250. Doi: http://dx.doi. org/10.1590/\$1413-73722011000200007

19. Larissa GS da, Maria CLH do, Rita CD de, Dagmar WV. Capacidade para o trabalho entre trabalhadores de higiene e limpeza de um hospital universitário público. Revista Eletrônica de Enfermagem. 2010; v. 12, n. 1, p. 158-163. Doi: http://dx.doi. org/10.5216/ree.v12i1.5788

20. Raffone AM, Hennington EA. Avaliação da capacidade funcional dos trabalhadores de enfermagem. Rev. Saúde Pública. 2005; v.39(4) p.669-676. Doi: http://dx.doi.org/10.1590/S0034$\underline{89102005000400023}$
21. Felli VEA. Implantação e Avaliação do Sistema de Monitoramento da Saúde do Trabalhador de Enfermagem (SIMOSTE). São Paulo; 2010. (Relatório final apresentado ao CNPq, para prestação de contas da Bolsa Produtividade-2, relativa ao período 20082011)

22. Costa FM da, Vieira MA, Sena RR de. Absenteísmo relacionado à doenças entre membros da equipe de enfermagem de um hospital escola. Rev. bras. enferm. 2009; v.62(1) p. 38-44. Doi: http://dx.doi.org/10.1590/s0034-71672009000100006.

23. Larissa GS da, Kiyomi NY. Estresse ocupacional em trabalhadores de uma unidade de internação de um hospital-Escola. Rev Ciên. e Cuidados em Saúde. 2008; v.7, n.1,p.98-105. http://dx.doi. org/10.4025/cienccuidsaude.v7il.4912

24. Maria FSA de, Fabíola MCO de. A atuação do enfermeiro na equipe de Saúde da Família e a satisfação profissional. Revista Eletrônica de Ciências Sociais, João Pessoa. 2009; n.14, v.1, p 3-14.

25. Silva RM. et al. Análise quantitativa da satisfação profissional dos enfermeiros que atuam no período noturno. Texto contexto - enferm. 2009; vol.18, n.2, p. 298-305. http://dx.doi. org/10.1590/S0104-07072009000200013

\section{Publish in International Archives of Medicine}

International Archives of Medicine is an open access journal publishing articles encompassing all aspects of medical science and clinical practice. IAM is considered a megajournal with independent sections on all areas of medicine. IAM is a really international journal with authors and board members from all around the world. The journal is widely indexed and classified Q1 in category Medicine. 